\title{
ERŐTANI VIZSGÁLATOK ACÉL SIMÍTÓ ESZTERGÁLÁSÁNÁL
}

\section{INVESTIGATION OF CUTTING FORCES ON STRUCTURAL STEEL IN CASE OF FINE TURNING}

\author{
Horváth Richárd ${ }^{1}$, Lukács Judit ${ }^{2}$ \\ ${ }^{1,2}$ Óbudai Egyetem, Bánki Donát Gépész és Biztonságtechnikai Mérnöki kar, H-1081 \\ Magyarország, Budapest, Népszinház utca, 8.; horvath.richard@bgk.uni-obuda.hu; \\ lukacs.judit@bgk.uni-obuda.hu
}

\begin{abstract}
The knowledge of cutting forces is very important, because they have a significant influence on load of machines as well as on deformation of workpieces. In turning operations the generated forces depend on material and cutting conditions, moreover on tool geometry, which defines the cross-section of chip (width and thickness). In this paper the technological specialities of fine turning were taken into consideration by using special parameters of chip cross-section. Investigations of force were made on C45 structural steel and new force model was generated, which can be applied in technological process planning to estimate the cutting forces in case of fine turning.
\end{abstract}

Keywords: fine turning, cutting force model, specific cutting force.

\section{Összefoglalás}

A forgácsoláskor fellépő erőhatások ismerete nagy jelentőséggel bír. A forgácsolási erő befolyással lehet a szerszámgép terhelésére, valamint a munkadarab deformálódására. Az esztergáláskor fellépő erőhatások az anyagjellemzőkön és forgácsolási adatokon kívül erősen függenek a forgács alakját (vastagság és szélesség) meghatározó szerszám élgeometriájától. A dolgozat a finomesztergálás technológiáját jellemző forgácsjellemzőket vezet be. C45-ös acélon erőtani vizsgálatokat végez, majd olyan új erő modellt hoz létre, amellyel a technológiai előtervezés során a várható erőhatások finomesztergálásnál jó közelítéssel becsülhetőek.

Kulcsszavak: finomesztergálás, erömodell, fajlagos forgácsolóerō.

\section{Bevezetés}

A forgácsolóerő értékének a meghatározása történhet méréssel illetve számítással. A közvetett mérésre lehetőség adódik üzemi körülmények között is. Ekkor a hajtómotor teljesítményfelvételéből következtetünk a forgácsolóerő $\left(F_{c}\right)$ nagyságára. Közvetlen mérés esetén az erőmérőt célszerü a munkadarab befogókészülékében, vagy a szerszám-tartóban elhelyezni. A gyakorlat- ban legelterjedtebb alkalmazás a nyúlásmérő bélyeges és a piezoelektromos elven történő erőmérés. Az előbbiek közül kétféle elrendezés jellemző. A legegyszerübb módszer, hogy a bélyegeket a késszárra ragasztják. Ez a főforgácsolóerő mérésére alkalmas, ami a késszár függőleges síkban való lehajlását okozza. Fetecau és társai [1] nevéhez füződik az ezzel a módszerrel történő, PTFE kísérleti forgácsolása során fellépő csekély nagyságú erök mérése. A másik 
konstrukciós változatnál erőmérő asztal közbeiktatásával rögzítik a szerszámbefogót a szánrendszerhez. Erre az elrendezésre mutatnak be saját fejlesztésü kivitelt Süleyman és társai [2]. A piezoelektromos elven alapuló erőmérés kiindulási jelensége az, hogy bizonyos kristályos anyagokban (pl. $\mathrm{SiO}_{2}$ ) erő hatására töltésátrendeződés megy végbe, így a két párhuzamos felülete között elektromos feszültség keletkezik. A piezo elven történő erőmérés lehet egy, illetve többkomponenses. Amennyiben a jeladók a tárgyasztalba vannak beépítve, akkor a munkadarabra ható erőket mérik. Ha van rá lehetőség, célszerü azonban a szerszám szárában, közvetlenül forgácsolóél alatt elhelyezni. Erre mutatnak példát Horváth és társai [3], akik a finomesztergálás technológiai tartományára fejlesztettek ki egy piezoelektromos elven müködő, kis erőtartományban tizedes pontosságú mérésekre alkalmas erőmérőt. Számos tanulmány foglalkozik a forgácsolási paraméterek, valamint a fellépő erőhatások közötti összefüggésekkel. Rao és társai [4], AISI 1050 acélt esztergáltak kerámia szerszámmal. Méréseik alapján megállapí-tották, hogy a forgácsolósebesség nagysága sem az erökomponensekre, sem pedig a felületi érdességre nincs jelentős hatással. Valamint az előtolás értéke mindkettőt számottevően befolyásolja, illetve a forgácsolóerő összetevőinek fogásmélységtől való függése lényeges, a felületi érdességé azonban elhanyagolható. Kundrák és társai [5] keményesztergálással megmunkált felületek mikro keménységének változását vizsgálták. Megállapították, hogy bár közvetlenül nincs hatással a forgácsoló erő a felület keménységére, a szakirodalom szerint közvetve azonban a rendszerbe bevezetett mechanikus energia hőenergiává való átalakulása miatt mégis hatással van. A hagyományos hosszesztergálástól gyakran eltérő geometriai és technológiai viszonyok miatt a rotációs esztergálásnál Sztankovics és társai $[6,7]$ bemutatták, hogy hogyan lehet meghatározni a forgácskeresztmetszetet jellemző paramétereket.

\section{Anyagok és módszerek}

\subsection{Felhasznált anyag, szerszám, esz- köz}

Kísérleteinket ötvözetlen, általános rendeltetésű szerkezeti acélon (C45) végeztük. Kémiai $\quad$ összetétele: $\quad \mathrm{C}=0,42-0,5 \%$; $\mathrm{Si} \leq 0,4 \% ; \quad \mathrm{Mn}=0,5-0,8 \% ; \quad \mathrm{P} \leq 0,045 \%$; $\mathrm{Mn} \leq 0,1 \% ; \mathrm{Ni}=\leq 0,4 \% ; \mathrm{Cr}+\mathrm{Ni}+\mathrm{Mo} \leq 0,63 \%$.

Az alkalmazott szerszám: keményfém, lapka kód: DCMT 11T304 FG TT8115 CVD bevonatos (TiN/TiCN/ $\mathrm{Al}_{2} \mathrm{O}_{3} / \mathrm{TiN}$ ). Gyártó: TaeguTec.

$\mathrm{Az}$ erőmérésre egy speciálisan átalakított késszárat használtunk [3], mely kifejezetten a finomesztergáláskor fellépő kis erők mérésére lett kifejlesztve. A késszár (mely mindhárom erőkomponens mérésére alkalmas) egy KISTLER 5019 Multichannel Charge Amplifier, háromcsatornás töltéserősítőhöz lett csatlakoztatva. $\mathrm{Az}$ erőértékeket DynoWare szoftver segítségével értékeltük ki.

\subsection{Kísérleti pontok meghatározása}

Az erőtani vizsgálatokra olyan kísérletterv készült, mely a finomesztergálás teljes tartományát magába foglalja: $f=0,03 \ldots 0,15$ $\mathrm{mm} ; a_{p}=0,25 \ldots 0,7 \mathrm{~mm}$. Megjegyzendő, hogy a kisebb fogásmélységek esetén kizárólagosan a csúcssugár végzi a forgácsleválasztást és a beállított legnagyobb érték esetén is csupán a föél egy rövid szakasza vesz benne részt.

\subsection{Erőmodell finomesztergálás tech- nológiájára}

Finomesztergáláskor, a forgácsleválasztást szinte kizárólag a szerszám csúcssugara végzi. Az elméleti deformálatlan forgácskeresztmetszet nagyságrendekkel kisebb, mint az általánosan használt Kienzle-Victor modellben [8]. Finomesztergáláskor nem hanyagolható el a csúcssugár hatása. A jel- 
lemző forgácskeresztmetszetet szemlélteti az 1. ábra.

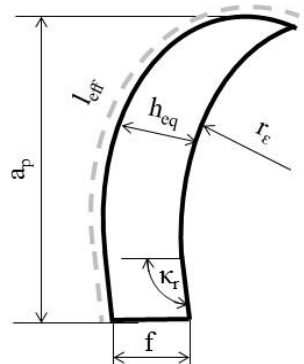

1. ábra. Finomesztergálásra jellemzö forgácskeresztmetszet

A fogásban levő, müködő élhossz meghatározása az alábbi módon lehetséges $[9,10]$ :

$$
l_{e f f}=\frac{a-r_{\varepsilon} \cdot\left(1-\cos \kappa_{r}\right)}{\sin \kappa_{r}}+\frac{2 \cdot r_{\varepsilon} \cdot \pi}{360^{\circ}} \cdot\left(\kappa_{r}+\arcsin \frac{f}{2 \cdot r_{\varepsilon}}\right)
$$

A beállított forgácsolási paraméterek alapján pedig kiszámítható az ekvivalens forgácsvastagság:

$$
\begin{aligned}
& A=a \cdot f=h \cdot b=h_{e q} \cdot l_{\text {eff }} \\
& h_{e q}=\frac{a \cdot f}{l_{\text {eff }}}
\end{aligned}
$$

A bevezetett forgácsolóerő modellben a fajlagos forgácsolóerő a következő alakban írható fel:

$$
k_{c}=\frac{F_{c}}{A}=\frac{F_{c}}{h_{e q} \cdot l_{\text {eff }}}
$$

A kapott $k_{c}$ értékek azonban függenek a $h_{e q}$ és a $l_{e f f}$ értékeitől, ezért ezeket kétfaktoros hatványfüggvény regresszióval modelleztük:

$$
k_{c}=C \cdot h_{e q}^{q_{c}} \cdot l_{e f f}^{y_{c}}
$$

A $h_{e q}=0,1 \mathrm{~mm}$ behelyettesítésével, megállapítható $k_{c 1,0.1}$ értéke:

$$
k_{c 1,0.1}=C \cdot 0,1^{q_{c}}
$$

Az alkalmazott új forgácsolóerő modell pedig:

$$
F_{c}=k_{c} \cdot h_{e q} \cdot l_{e f f}=k_{c 1,0.1} \cdot 10^{q_{c}} \cdot h_{e q}{ }^{1+q_{c}} \cdot l_{e f f}{ }^{1+y_{c}}
$$

\section{Eredmények}

A kísérleti pontokat és azok beállításait, valamit a mért erőértékeket ismerteti az 1 . táblázat. A forgácsoló sebességet konstans $\mathrm{v}_{\mathrm{c}}=300 \mathrm{~m} / \mathrm{min}$ értéken tartottuk.

1. táblázat. Mért $F_{c}$ és $k_{c}$ értékek

\begin{tabular}{|c|c|c|c|c|}
\hline $\begin{array}{c}\text { Kísérleti } \\
\text { pontok }\end{array}$ & $a_{p,}$ & $f, m$ & $F_{c}, N$ & $\begin{array}{c}k_{c} \\
N / m^{2}\end{array}$ \\
\hline 1. & 0,25 & 0,03 & 41 & 5492 \\
\hline 2. & 0,25 & 0,05 & 51 & 4075 \\
\hline 3. & 0,25 & 0,07 & 63 & 3599 \\
\hline 4. & 0,25 & 0,09 & 70 & 3120 \\
\hline 5. & 0,25 & 0,11 & 78 & 2845 \\
\hline 6. & 0,25 & 0,13 & 88 & 2718 \\
\hline 7. & 0,25 & 0,15 & 100 & 2667 \\
\hline 8. & 0,5 & 0,03 & 70 & 4667 \\
\hline 9. & 0,5 & 0,05 & 96 & 3836 \\
\hline 10. & 0,5 & 0,07 & 126 & 3586 \\
\hline 11. & 0,5 & 0,09 & 142 & 3156 \\
\hline 12. & 0,5 & 0,11 & 161 & 2924 \\
\hline 13. & 0,5 & 0,13 & 184 & 2823 \\
\hline 14. & 0,5 & 0,15 & 214 & 2853 \\
\hline 15. & 0,7 & 0,03 & 91 & 4321 \\
\hline 16. & 0,7 & 0,05 & 124 & 3543 \\
\hline 17. & 0,7 & 0,07 & 168 & 3427 \\
\hline 18. & 0,7 & 0,09 & 185 & 2937 \\
\hline 19. & 0,7 & 0,11 & 216 & 2808 \\
\hline 20. & 0,7 & 0,13 & 246 & 2703 \\
\hline 21. & 0,7 & 0,15 & 288 & 2743 \\
\hline & & & & \\
\hline
\end{tabular}

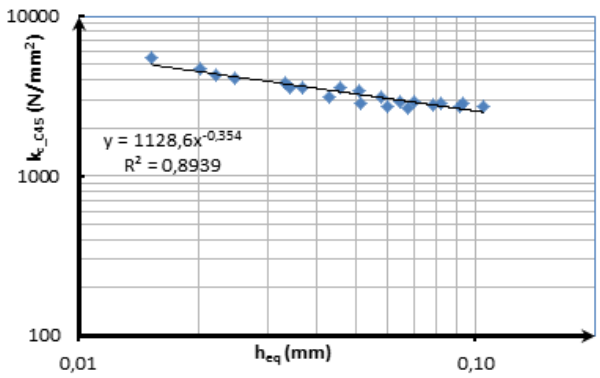

2. ábra. Fajlagos forgácsoló erö a közepes forgácsvastagság függvényében

A fajlagos főforgácsolóerő értékei az ekvivalens forgácsvastagság függvényében 
logaritmikus léptékủ diagramon ábrázolva egy egyenesre illeszkednek (2. ábra).

Tehát az (5) egyenletnek megfelelően a fajlagos forgácsoló erő modellje az alábbi:

$$
k_{c_{-} C 45}=1015 \cdot h_{e q}^{-0,399} \cdot l_{\text {eff }}^{0,095}
$$

A fajlagos forgácsoló erő és a $\mathrm{k}_{\mathrm{c} 1,0.1}$ meghatározása utána az (7) erőmodell az alábbi:

$$
F_{c_{-} C 45}=2542 \cdot 10^{-0,399} \cdot h_{e q}^{0,601} \cdot l_{e f f}^{1,095}
$$

\subsection{Erőmodell ellenőrzése}

Ha grafikonon ábrázoljuk a mért és számított főforgácsolóerőket, akkor a létrejövő ponthalmazra egy egyenest lehet illeszteni. Az ábrázolt pontok eltérése az $x=y$ egyenestől megmutatja az egyenlet becslési hibáját (3. ábra).

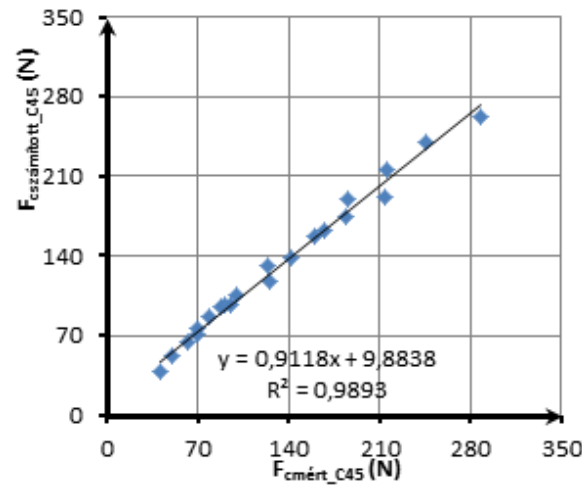

3. ábra. A számitott forgácsolóerők a mért értékek függvényében

\section{Konklúzió}

A dolgozat a finomesztergálás technológiájára mutat be egy új erőmodellt, mely a Kienzle-Victor formulából indul ki de figyelembe veszi a finomesztergáláskor kialakuló forgácskeresztmetszet jellegét.

A modellbe bevezettük a $h_{e q}$ és $l_{\text {eff }}$ forgácskeresztmetszet jellemzőket. A forgácskeresztmetszetek a simításra jellemző módon kisebbek, ezért bevezetésre került az ún. $k_{c 1.0,1}$, forgácsolóerő fajlagos foértéke. (mely $l_{e f f}=1 \mathrm{~mm}$; és $h_{e q}=0,1 \mathrm{~mm}$ forgácskeresztmetszethez tartozik).

A fajlagos forgácsoló erőre $\left(k_{c}\right)$ és a forgácsolóeröre $\left(F_{c}\right)$ felépített modellek nagy pontossággal leírják és modellezik a mérések során meghatározott értékeket.

\section{Szakirodalmi hivatkozások}

[1] Catalin Fetecau, Felicia Stan: Study of cutting force and surface roughness in the turning of polytetrafluoroethylene composites with a polycrystalline diamond tool, Measurement 45 (2012) 1367-1379.

[2] Süleyman Yaldiz, Faruk Ünsacar, Haci Saglam, Hakan Isik: Design, development and testing of a four-component milling dynamometer for the measurement of cutting force and torque, Mechanical Systems and Signal Processing 21 (2007) 1499-1511.

[3] Horváth Richárd, Pálinkás Tibor, Mátyási Gyula: Erömérő rendszer tervezése, kivitelezése és adaptációja finomesztergáláskor fellépö kis erők méréséhez, GÉP 59:(6) (2013) 48-53.

[4] C. J. Rao, D. Nageswara Rao, P. Srihari: Influence of cutting parameters on cutting force and surface finish in turning operation, Procedia Engineering 64 (2013) 1405-1415

[5] J. Kundrak, A. G. Mamalis, K. Gyani, V. Bana: Surface layer microhardness changes with high-speed turning of hardened steels, International Journal of Advanced Manufacturing Technology 53:(1-4) (2011) 105-112.

[6] I. Sztankovics, J. Kundrak: Determination of the Chip Width and the Undeformed Chip Thickness in Rotational Turning, Key Engineering Materials 581 (2014) 131-136.

[7] I. Sztankovics, J. Kundrak: Effect of the inclination angle on the defining parameters of chip removal in rotational turning, Manufacturing Technology 14:(1) (2014) 97104.

[8] O. Kienzle, H. Victor: Die bestimmung von kräften und leistungen an spanenden werkzeugmaschinen, VDI-Z 94 (1952) 299-305.

[9] S.R. Frey: Repetitorium: Spanende Formung Schweizer Maschinenmarkt, 32 (1980) 26-29

[10] C. Bus, N. A. L. Touwen, P. C. Veenstra, A. C. H. Van Der Wolf: On the Significance of Equivalent Chip Thickness, Annals of the CIRP, XVIV. (1971) 121-124 